\title{
Pemberdayaan Tim Pengembang Kurikulum (TPK) Pendidikan Dasar dan Menengah
}

\author{
Ambari Sutardi \\ Pusat Kurikukum, Balitbang, Kemdiknas
}

\begin{abstract}
Abstrak: Tujuan studi dimaksudkan untuk memperoleh informasi dari daerah sampel tentang: Pembentukan Tim Pengembang Kurikulum (TPK) pendidikan dasar dan menengah; struktur kepengurusan, siapa dan berapa jumlah anggotanya; keberadaan dana bagi TPK; pemahaman anggota terhadap kebijakan Pemerintah yang berkaitan dengan kurikulum; pemberdayaan mereka melaksanakan tugas pokok antara lain mensosialisasikan kebijakan dan mendampingi sekolah menyusun kurikulum; dan pelaksanaan kurikulum di sekolah. Hasil studi menunjukkan bahwa semua daerah sampel telah membentuk TPK; ada struktur kepengurusannya dengan jumlah anggota bervariasi; dana belum tersedia secara memadai di beberapa daerah; tingkat pemahaman responden terhadap kebijakan bervariasi; hanya sebagian anggota TPK yang diberdayakan sesuai TUPOKSInya; pelaksanaan KTSP di sekolah belum merata.
\end{abstract}

Kata kunci: pemberdayaan, pengembang kurikulum (KTSP), pendidikan dasar dan menengah, dan tugas pokok.

Abstract: The objective of the study is to get information from some sample areas about: the establishment of curriculum developers team (CDT) for basic and secondary education; the structure of its caretaker, who and how many of its members; the availability of a budget needed; the members' understanding of the government policies related to curriculum; the empowerment of its members to do their main tasks among other things: socializing the policies and helping schools within basic and secondary educations writing up their respective curriculum; and school-based curriculum (S-BC) implementation. The data shows that all sample districts/municipalities have already established CDT; there is its caretaker structure with a various number of members; there is no sufficient budget in some districts/municipalities; there are some degrees of the members'understanding about the government policies related to curriculum; Districts/Municipalities Ministry of National Education empowered only some of the members socializing the government policies and helping schools writing up their curriculum as their main tasks; the implementation of S-BC was still uneven.

Key words: empowerment, curriculum developers (S-BC), primary and secondary education, function and task

\section{Pendahuluan}

Pusat Kurikulum, Badan Penelitian dan Pengembangan, Departemen Pendidikan Nasional sejak kira-kira tahun 90 an membentuk Jaringan Kurikulum yang dikenal dengan istilah JARKUR di tingkat Provinsi di seluruh Indonesia melalui Dinas Pendidikan Provinsi. Tujuannya agar ada suatu tim pada tingkat Provinsi yang anggotanya dapat bekerjasama dengan Pusat Kurikulum dalam mengembangkan kurikulum pendidikan dasar dan menengah, memantau pelaksanaannya dan menilainya agar hasilnya dapat dijadikan bahan penyempurnaan kurikulum berikutnya. Mereka terdiri dari unsur pengawas, kepala sekolah dan guru dari jenjang pendidikan dasar dan menengah. Menjadi anggota tim melalui proses seleksi cukup ketat termasuk penguasaan bahasa Inggris pada waktu itu.

Selama dalam perjalanannya, tim yang pada awalnya sering disebut sebagai tim perekayasa kurikulum (TPK) tugasnya kurang maksimal karena berbagai kendala. Misalnya pengurus dan anggotanya tidak ada pejabat dari Dinas Pendidikan Provinsi sehingga memberi kesan terlepas dari instansi tersebut, begitu pula dengan adanya anggota yang memasuki usia pensiun, pindah 
tugas, dan sebagainya. Akibatnya, bila Pusat Kurikulum bekerjasama dengan dan menyelenggarakan kegiatan di Dinas Pendidikan Provinsi, anggota TPK sering tidak dilibatkan karena kendala tersebut, dan kondisi ini terjadi tidak di semua provinsi. Kondisi seperti ini berlangsung cukup lama, namun Pusat Kurikulum tetap berupaya agar anggota TPK diberdayakan secara proporsional, maksimal sesuai dengan tupoksinya.

Adanya kebijakan pemerintah untuk menyempurnakan kurikulum 94 menjadi kurikulum berbasis kompetensi yang dikenal dengan KBK 2004 merupakan dorongan terhadap Pusat kurikulum untuk lebih proaktif bekerjasama dengan Dinas Pendidikan Provinsi guna mengaktifkan kembali anggota TPK. Hal ini beralasan mengingat pada kenyataannya banyak informasi baru yang berkaitan dengan perubahan kurikulum yang harus disampaikan kepada instansi terkait di daerah termasuk sekolah. Pada saat itu kerjasama lebih difokuskan pada pentingnya melibatkan anggota TPK dalam menyampaikan informasi kepada guru dan instansi yang relevan untuk mengembangkan, mengawasi pelaksanaan dan menilai kurikulum pendidikan dasar dan menengah di tingkat provinsi. Untuk itu, agar ada kepastian status mereka sebagai anggota TPK, sangat diharapkan Dinas Pendidikan Provinsi membentuk TPK dengan surat keputusan.

Pada waktu yang bersamaan Pusat Kurikulum mengembangkan gagasan untuk lebih memperluas jaringan kerjasama dengan Dinas Pendidikan Kabupaten/Kota. Adanya kepastian perubahan KBK menjadi standar isi (SI) 2006, gagasan lebih dimantapkan dan mulai membuka jaringan serupa dengan Dinas Pendidikan Kabupaten/Kota di seluruh Indonesia dengan tujuan yang sama. Berbagai informasi tetang perubahan dari KBK menjadi SI yang dikemas dalam bentuk kebijakan, panduan dan atau petunjuk teknis lainnya ditujukan kepada semua pihak yang berkepentingan, termasuk guru tanpa kecuali untuk dipahami dan dilaksanakan oleh mereka dengan baik. Karena itu informasi ini harus disampaikan kepada mereka tepat waktu secara merata, baik dalam penyebaran maupun dalam kaitannya dengan kualitas informasi yang diterima mereka secara menyeluruh, termasuk mereka yang berada di pedalaman sekalipun.
Hal ini penting mengingat sekolah secara keseluruhan merupakan suatu kesatuan yang menerima materi yang sama yang harus dicapai oleh peserta didik dalam waktu yang relatif sama karena terikat oleh suatu sistem yang sama yaitu adanya ujian nasional. Agar kondisi dimaksud tercipta, pemerintah melalui Menteri Pendidikan Nasional mengeluarkan surat keputusan yang dikenal dengan Peraturan Menteri Pendidikan Nasional (Permendiknas) Nomor 24, Tahun 2006 Tentang Pelaksanaan Standar Isi dan Standar Kompetensi Lulusan untuk Satuan Pendidikan Dasar dan Menengah yang menegaskan "satuan pendidikan dasar dan menengah harus sudah mulai menerapkan Peraturan Menteri Pendidikan Nasional Nomor 22 Tahun 2006 tentang Standar Isi untuk Satuan Pendidikan Dasar dan Menengah dan Permendiknas Nomor 23 Tahun 2006 tentang Standar Kompetensi Lulusan untuk Satuan Pendidikan Dasar dan Menengah paling lambat tahun ajaran 2009/2010" (Pasal 2, Ayat 2).

Adanya tuntutan mendesak dari pemerintah untuk agar sekolah melaksanakan Standar Isi (SI) dan Standar Kompetensi Lulusan (SKL) mengisyaratkan perlu ada upaya nyata pembentukan jaringan kurikulum yang lebih luas melalui Dinas Pendidikan di tingkat Kabupaten/Kota dan keberadaannya menjadi suatu keharusan. Jaringan kurikulum di hampir seluruh Kabupaten/Kota telah terbentuk yang disebut Tim Pengembang Kurikulum (TPK). Tugas pokok Tim ini antara lain mensosialisasikan kebijakan pemerintah yang berkaitan dengan kurikulum dan mendampingi sekolah jenjang pendidikan dasar dan menengah menyusun kurikulum termasuk sekolah di daerah pedalaman. Karena itu fungsi TPK Kabupaten/ Kota menjadi penting sehingga mensyaratkan anggotanya harus professional, memiliki wawasan yang luas tentang pendidikan umumnya dan kurikulum khususnya. Pentingnya peran tim maka keberadaannya, ketersediaan dana yang dapat dimanfaatkan bagi kegiatan TPK Kabupaten/Kota, wawasan dan kompetensi setiap anggotanya, pemberdayaannya oleh Dinas Pendidikan Kabupaten/kota untuk melaksanakan tugas pokoknya serta dampaknya terhadap pelaksanaan kurikulum tingkat satuan pendidikan (KTSP) perlu diteliti.

Data yang diperoleh dari beberapa Dinas Pendidikan Kabupaten/Kota hingga akhir tahun 
2008 menunjukkan bahwa Dinas Pendidikan belum membentuk TPK dengan surat pengangkatan yang disahkan oleh Kepala Dinas atau Bupati. Di beberapa daerah lainnya Dinas Pendidikan sudah membentuk TPK dengan surat keputusan, namun anggotanya belum diberdayakan secara maksimal. Rumusan masalah penelitian adalah sbb: 1) Apakah pihak Dinas Pendidikan Kabupaten/Bupati telah membentuk TPK dengan surat mengangkatan?; 2) Apakah ada struktur kepengurusan TPK dan siapa serta berapa jumlah anggotanya?; 3) Apakah ada dana yang mendukung pelaksanaan kegiatan bagi anggota TPK; 4) Apakah semua anggota TPK telah memahami kebijakan pemerintah yang berkaitan dengan kurikulum?; 5) Apakah semua anggota TPK relatif sama diberdayakan untuk melaksanakan tugas pokok mereka antara lain mensosialisasikan kebijakan pemerintah tersebut dan mendampingi sekolah menyusun kurikulum?; 6) Setelah tiga tahun diberlakukan kebijakan pemerintah yang berkaitan dengan kurikulum sekolah, apakah sekolah di jenjang pendidikan dasar dan menengah di daerah sampel telah melaksanakannya secara merata?.

Tujuan studi untuk memperoleh informasi dari daerah sampel tentang: 1) Pembentukan TPK pendidikan dasar dan menengah; 2) Struktur kepengurusan, siapa dan berapa jumlah anggotanya; 3) Keberadaan dana bagi TPK; 4) Pemahaman anggota terhadap kebijakan pemerintah yang berkaitan dengan kurikulum; 5) pemberdayaan mereka melaksanakan tugas pokok antara lain mensosialisasikan kebijakan dan mendampingi sekolah menyusun kurikulum; dan 6) Pelaksanaan kurikulum di sekolah.

\section{Kajian Literatur}

Ditegaskan secara rinci di dalam Panduan yang disusun oleh Pusat Kurikulum bahwa peran TPK Kabupaten/Kota sebagai mediator, fasilitator/ pendamping, dan inovator dalam rangka membantu tugas Dinas Pendidikan Kabupaten/ Kota yang berkaitan dengan pengembangan, implementasi, monitoring dan evaluasi kurikulum muatan lokal dan kurikulum tingkat satuan pendidikan di berbagai jenis dan jenjang pendidikan. Mediator berkenaan dengan peran Jaringan Kurikulum dalam membantu mensosialisasikan berbagai kebijakan tentang kurikulum dari pemerintah pusat ke pemerintah daerah dan lembaga-lembaga pendidikan di daerah. Fasilitator atau pendamping berkenaan dengan peran Jarkur dalam memberikan bantuan teknis kepada satuan pendidikan dan perorangan mengenai pengembangan, implementasi, dan evaluasi kurikulum. Inovator berkenaan dengan peran Jaringan Kurikulum dalam mengembangkan, mengkaji, dan menemukan model implementasi kurikulum dan sarana pendukung pembelajaran yang sesuai dengan kondisi dan karakteristik daerah.

Adapun tugasnya membantu Dinas Pendidikan Kabupaten/Kota dalam hal: a) Mensosialisasikan kebijakan pemerintah dalam bidang pendidikan khususnya kurikulum; b) Mengembangkan kurikulum muatan lokal; c) Menyelenggarakan pelatihan pengembangan kurikulum bagi calon pengembang kurikulum di daerah dan lembaga pendidikan; d) Mengembangkan modelmodel kurikulum dan implementasinya; e) Mengembangkan model-model sarana pendukung pembelajaran; f) Melaksanakan monitoring dan evaluasi penerapan standar nasional pendidikan yang terkait dengan pengembangan kurikulum dan implementasinya; dan g) Menyediakan layanan dan konsultasi kurikulum dan pembelajaran bagi pihak yang membutuhkan"(Pusat Kurikulum, 2006).

Keberadaan panduan dari Pusat Kurikulum didukung oleh adanya Surat Edaran Menteri Pendidikan Nasional Nomor 33/MPN/SE/2007 yang menekankan perlunya pembentukan Tim sosialisasi KTSP di setiap Kabupaten/kota dengan tugas: a. melakukan sosialisasi Permendiknas Nomor 22 Tahun 2006 dan Permendiknas Nomor 23 Tahun 2006 kepada seluruh satuan pendidikan dasar dan menengah di wilayah kabupaten/kota; b. melatih dan membina secara terus menerus dalam pengembangan KTSP kepada satuan pendidikan dasar dan menengah di wilayah kabupaten/kota; c. Pemerintah Kabupaten/Kota memberi dukungan dana agar Tim dapat melakukan tugas sebaik-baiknya".

Surat Edaran tersebut sejalan/mendukung Peraturan Pemerintah (PP) Nomor 38 Tahun 2007 Tentang Pembagian Urusan Pemerintahan antara Pemerintah, Pemerintah Daerah Provinsi dan Pemerintah daerah Kabupaten/Kota. Bab II 
Tentang Urusan Pemerintahan, bidang urusan pemerintahan meliputi pendidikan (ayat 4). Bab III Tentang Pembagian Urusan Pemerintahan, Pasal 6 ayat 2 Tentang Urusan Pemerintahan...... "Kabupaten/kota terdiri atas urusan wajib dan urusan pilihan" sedangkan Pasal 7 ayat 2 berbunyi "urusan wajib meliputi pendidikan".

Hubungannya dengan himbauan dukungan dana yang tertuang di dalam surat edaran di atas, pemerintah dan DPR sebelumnya telah memfasilitasi dana dengan mengamandemen payung hukumnya, yaitu Undang-Undang Dasar (UUD)'45. Setelah diamandemen, pasal 31 UUD'45 berbunyi: "negara memprioritaskan anggaran pendidikan sekurang-kurangnya dua puluh persen dari anggaran pendapatan dan belanja negara serta dari anggaran pendapatan dan belanja daerah untuk memenuhi kebutuhan penyelenggaraan pendidikan nasional (ayat 4)", (WIKISOURCE). Untuk itu "Pemerintah dan Pemerintah daerah wajib memberikan layanan dan kemudahan, serta menjamin terselenggaranya pendidikan yang bermutu bagi setiap warga negara tanpa diskriminasi" (BAB IV, Pasal 11, ayat 1-UUSPN Nomor 20 Tahun 2003). Ini menganjurkan bahwa pihak yang berwenang di daerah juga harus memberi layanan dan kemudahan bagi guru dimanapun berada agar mereka pada akhirnya dapat menyelenggarakan proses pembelajaran yang bermutu di kelas seperti halnya teman mereka yang mengajar di daerah perkotaan.

Adanya Undang-Undang Sistem Pendidikan Nasional (UUSPN) Tahun 2003, PP Nomor 19, Tahun 2005, delapan standar nasional pendidikan dan dua diantaranya adalah standar isi (SI) 2006 dan standar proses yang berkaitan dengan perubahan kebijakan pemerintah tentang kurikulum pendidikan dasar dan menengah yang sekarang sedang berlaku dan dikenal dengan istilah kurikulum tingkat satuan pendidikan (KTSP), serta panduan dan atau petunjuk teknis tentang pelaksanaan kebijakan dimaksud yang dijabarkan di dalam panduan penyusunan kurikukum tingkat satuan pendidikan jenjang pendidikan dasar dan menengah dari Badan Standar Nasional Pendidikan (BSNP) Tahun (2006) merupakan substansi/informasi makro dan penting.

Secara garis besar SI berisi antara lain: 1) kerangka dasar dan struktur kurikulum yang merupakan pedoman dalam penyusunan kurikulum pada tingkat satuan pendidikan; 2) beban belajar bagi peserta didik pada satuan pendidikan dasar dan menengah; 3) kurikulum tingkat satuan pendidikan yang akan dikembangkan oleh satuan pendidikan berdasarkan panduan penyusunan kurikulum sebagai bagian tidak terpisahkan dari standar isi, dan 4) kalender pendidikan untuk penyelenggaraan pendidikan pada satuan pendidikan jenjang pendidikan dasar dan menengah.

Standar Isi Tahun 2006 meliputi informasi tentang berbagai hal yang berkaitan dengan tugas guru sehari-hari, antara lain: kewenangan setiap satuan pendidikan di jenjang pendidikan dasar dan menengah menyusun kurikulum sendiri, siapa yang menyusunnya, bagaimana sistematikanya dan menjabarkannya hingga menjadi rencana pelaksanaan pembelajaran (RPP); fleksibilitas bagi sekolah untuk menambah 4 (empat) jam pelajaran per minggu untuk mata pelajaran apa saja yang dianggap perlu di tambah jamnya; pendekatan tematik di kelas rendah (kelas 1, 2, dan 3) di SD dimana dalam pelaksanaan pembelajaran materi dari beberapa mata pelajaran diikat oleh suatu tema; program life skill atau keterampilan hidup; muatan lokal yaitu mata pelajaran yang ditentukan bukan oleh pemerintah melainkan oleh daerah sendiri, serta batasan memberi tugas kepada peserta didik.

Kewenangan sekolah menyusun kurikulum berkenaan dengan adanya otonomi sekolah yang mengharuskan sekolah menyusun kurikulum sendiri dan hal ini juga berlaku di beberapa negara lain dengan istilah School-Based Curriculum. Pada kenyataannya "School-Based Curriculum Development can range from individual teachers interpreting and adapting existing curricula, to whole staff working together to create curricula, sometimes with input from students, or people from outside the school" (Rachel Bolstad, 2004).

Kebijakan tentang diperbolehkan sekolah menyusun kurikulum mereka masing-masing merupakan kesempatan baik bagi mereka untuk berkreasi mengembangkan gagasan yang dapat dituangkan di dalam dokumen kurikulum yang diaplikasikan di dalam proses pembelajaran di kelas. KTSP harus merupakan hasil rekayasa warga sekolah masing-masing dan bukan merupakan hasil adopsi secara berkesinambung- 
an karena bila sekolah mengadopsi secara terus menerus dari sekolah lain, hal ini akan sangat memungkinkan kurikulum mereka tidak sesuai dengan kondisi daerah dan peserta didiknya.

Ada panduan penyusunan KTSP tahun 2006 untuk Satuan Pendidikan Jenjang Pendidikan Dasar dan Menengah dari Badan Standar Nasional Pendidikan (BSNP, 2006). Di dalam panduan tersebut dijelaskan antara lain siapa yang berhak menyusun kurikulum sekolah, langkah apa yang harus ditempuh, komponen apa saja di dalamnya, siapa yang menetapkan dan kapan mulai berlaku.

Panduan BSNP memberi inspirasi bagi para pengembang kurikulum tingkat satuan pendidikan pada jenjang pendidikan dasar dan menengah dalam mengembangkan kurikulum yang sesuai dengan situasi dan kondisi tempat sekolah berada. Yang pertama dan perlu diingat oleh para pengembang kurikulum berbasis sekolah yaitu tentang definisi kurikulum itu sendiri, yaitu "seperangkat rencana dan pengaturan mengenai tujuan, isi, dan bahan pelajaran serta cara yang digunakan sebagai pedoman penyelenggaraan kegiatan pembelajaran untuk mencapai tujuan pendidikan tertentu" (UUSPN No. 20 Tahun 2003 Bab 1, Pasal 1, ayat 19). Pasal 1 ayat 1 menyatakan "Satuan pendidikan dasar dan menengah mengembangkan dan menetapkan kurikulum tingkat satuan pendidikan dasar dan menengah sesuai kebutuhan satuan pendidikan yang bersangkutan" (Permendiknas No 24, Tahun 2006), pasal 1 , ayat 1 ).

Standar Proses 2007 untuk satuan pendidikan dasar dan menengah merupakan panduan dalam melaksanakan rangkaian kegiatan mulai dari perencanaan dan pelaksanaan pembelajaran. Bagaimana guru menyusun perencanaan dan pelaksanaan pembelajaran yang ideal sesuai dengan aturan yang sedang berlaku. Ditegaskannya "Standar proses untuk satuan pendidikan dasar dan menengah mencakup perencanaan proses pembelajaran, pelaksanaan proses pembelajaran, penilaian hasil pembelajaran, dan pengawasan proses pembelajaran" (Standar Proses 2007, pasal 1, ayat 1). Standar ini juga menegaskan pentingnya peserta didik mencapai tidak hanya konsep tetapi juga kompetensi yang indikatornya adalah perilaku yang dapat diukur dan/atau diobservasi untuk menunjukkan keter- capaian kompetensi dasar tertentu yang menjadi acuan penilaian mata pelajaran. Indikator pencapaian kompetensi dirumuskan dengan menggunakan kata kerja operasional yang dapat diamati dan diukur, yang mencakup "pengetahuan, sikap, dan keterampilan" (Permendiknas, Nomor 41, Tahun 2007, Bab III Bagian B Tentang Pelaksanaan Pembelajaran). Ungkapan yang senada juga dinyatakan WIKIPEDIA, 2009 sebagai berikut "competence...encompasses a combination of knowledge, skills and behaviour utilized to improve performance"-kompetensi meliputi suatu kombinasi/perpaduan antara pengetahuan, keterampilan dan sikap.

Perubahan penekanan yang harus dicapai peserta didik dari penguasaan "konsep" ke "kompetensi" memberi kesan sederhana, namun sangat mendasar dan berdampak sangat luas, meliputi semua sekolah di jenjang pendidikan dasar dan menengah di seluruh Indonesia. Misalnya dari suasana di dalam kelas peserta didik pasif menjadi aktif, dari suasana di kelas cenderung tidak gaduh menjadi gaduh, dari guru lelah dengan tugasnya menyampaikan materi ajar melalui ceramah menjadi tidak lelah karena fungsinya bergeser menjadi fasilitator. Kondisi ini sejalan dengan kebijakan pemerintah yang menganjurkan bahwa kegiatan pembelajaran dilaksanakan "secara interaktif, inspiratif, menyenangkan, menantang, memotivasi peserta didik untuk berpartisipasi aktif, serta memberikan ruang yang cukup bagi prakarsa, kreativitas, dan kemandirian sesuai dengan bakat, minat, dan perkembangan fisik serta psikologis peserta didik" (PP Nomor 19 Tahun 2005, Bab IV, pasal 19, ayat 1). Peraturan pemerintah dan standar proses ini didukung oleh instruksi presiden Nomor 1, Tahun 2010 yang menegaskan pentingnya pembelajaran aktif.

Tuntutan ini akan terlaksana bila materi yang disajikan tidak terlalu sulit dan tidak terlalu mudah sehingga merupakan tantangan bagi mereka - the task that is going to help the learner learn more.... is one that is demanding but not too demanding, that provides support but not too much support. The difference between demands and support creates the space for growth and produces opportunities for learning". (Cameron, L., 2001). Adanya kesesuaian materi ini diharapkan akan memberi memotivasi 
peserta didik untuk "berpartisipasi aktif, serta memberikan ruang yang cukup bagi prakarsa, kreativitas, dan kemandirian sesuai dengan bakat, minat, dan perkembangan fisik serta psikologis peserta didik" (PP 19, Bab IV)

Harapan pemerintah terhadap adanya kegiatan pembelajaran di kelas yang menciptakan peserta didik mengadakan interaksi dengan pendidik dan teman mereka untuk aktif dan kreatif merupakan langkah baik. Hal yang serupa sebenarnya dulu pernah menggema dimanamana yang bermula dengan adanya proyek CBSACara Belajar Siswa Aktif. Kemudian selesai proyek ini disusul dengan istilah PAKEM- Pembelajaran Aktif Kreatif Efektif dan Menyenangkan, yang diselenggarakan oleh instansi yang berbeda. Bila dicermati keduanya, penekanan pelaksanaannya di kelas sama yaitu peserta didik dituntut untuk terlibat aktif selama pembelajaran berlangsung.

Dengan adanya TPK di setiap Kabupaten/ Kota serta fungsi dan tugasnya yang jelas, berbagai informasi mengenai KTSP dalam bentuk kebijakan, panduan dan atau petunjuk teknis berkaitan dengan kurikulum pendidikan dasar dan menengah diharapkan sampai kepada semua pihak yang berkepentingan secara cepat, benar dan merata. Hal ini penting agar pelaksanaan KTSP berjalan secara simultan di semua sekolah di seluruh tanah air tanpa mengabaikan kualitas pelaksanaannya. Harapan ini beralasan mengingat pengalaman menunjukkan bahwa luasnya wilayah dan terbatasnya sumberdaya manusia dan dana dari pusat menjadi kendala dalam menyampaikan hal-hal penting secara cepat dan merata kepada guru di seluruh tanah air.

\section{Metodologi Penelitian \\ Populasi dan Sampel}

Populasi dari studi kasus ini adalah semua TPK Kabupaten/kota sedangkan sampelnya adalah 12 (dua belas) TPK Kabupaten/Kota, meliputi Kabupaten Kuningan, Majalengka, Purwakarta, dan Kabupaten Bekasi di Provinsi Jawa Barat; Padangsidempuan di Provinsi Sumatera Utara; Kota Palangkaraya, Kabupaten Katingan dan Kotawaringin Timur di Provinsi Kalimantan Tengah; Kabupaten Barru dan Bulukumba di Provinsi Sulawesi Selatan; Kabupaten Boalemo di Provinsi
Gorontalo, Kota Yogyakarta di daerah Istimewa Yogyakarta. Pemilihan sampel menggunakan teknik Purposive random sampling di mana penelitian diselenggarakan berbarengan dengan penataran bagi anggota TPK di kedua belas daerah tersebut.

Penataran diselenggarakan oleh Pusat Kurikulum bekerjasama dengan Dinas Pendidikan Kabupaten/Kota setempat. Yang diundang adalah sebagian anggota TPK Kabupaten/Kota yang dalam hal ini mereka juga merangkap sebagai responden sebanyak 34 (tiga puluh empat) orang di setiap kabupaten/Kota dengan rincian "8(delapan) dari Dinas Pendidikan Kabupaten, 2 (dua) dari pendidikan anak usia dini (PAUD), 4 (empat) dari SD, 6 (enam) dari SMP, 8(delapan) dari SMA, 4 (empat) dari SMK, 2 (dua) dari SLB. (Pusat Kurikulum: Panduan Bantek Kabupaten/ Kota Tahun 2009). Jumlah responden penelitian dari masing-masing lembaga/institusi secara keseluruhan adalah: Dinas Kabupaten/Kota sebanyak 96, PAUD 24, SD 48, SMP 72, SMA 96, SMK 48, SLB 24, sehingga jumlah responden keseluruhan dalam studi ini menjadi 408 (empat ratus delapan) orang.

\section{Instrumen}

Instrumen yang digunakan adalah: 1. Panduan wawancara/diskusi, 2.Kuesioner tentang pemberdayaan anggota TPK, 3. Kuesioner Pelaksanaan KTSP di sekolah, 4. Panduan verifikasi KTSP.

\section{Waktu dan Teknik Pengumpulan Data}

Penelitian diselenggarakan selama tahun 2009 dan proses pengumpulan data: Pertama, mengundang anggota TPK untuk dijadikan responden. Pelaksanaan kegiatan pada umumnya di selenggarakan di Dinas Pendidikan setempat. Responden dikelompokan berdasarkan satuan pendidikan, PAUD, SD, SMP, SMA, SMK, dan SLB, sedangkan responden dari Dinas pendidikan mengikuti kelompok satuan pendidikan berdasarkan tugas bidang dikantor mereka masing-masing. Setiap kelompok diberi instrumen dua dan empat, sedangkan instrumen tiga diberikan kepada kepala Dinas Pendidikan setempat. Sesi terakhir responden tidak berkelompok dan diadakan wawancara/diskusi fokus tentang permasalahan 
atau kekurangpahaman mereka tentang substansi khususnya yang berkaitan dengan KTSP dan permasalahan lainnya yang relevan.

\section{Teknik analisis data}

Data yang diperoleh dianalisis secara deskriptif dengan bantuan komputer dan dipilah berdasarkan aspek yang tertuang di dalam rumusan permasalahan.

\section{Hasil Penelitian dan Bahasan}

Hasil studi dipilah menjadi beberapa klasifikasi; pembentukan TPK, struktur kepengurusan, keberadaan dana, pemahaman substansi, dan pemberdayaan anggotanya serta pelaksanaan KTSP.

\section{Pembentukan TPK}

Data menunjukkan bahwa di seluruh Kabupaten/ Kota yang menjadi daerah sampel telah dibentuk Tim Pengembang Kurikulum untuk jenjang pendidikan dasar dan menengah dan pembentukan disahkan dengan surat keputusan. Di beberapa daerah Surat Keputusan disahkan oleh Kepala Dinas Pendidikan dan di daerah lainnya oleh Bupati atau wakikota. Pembentukan TPK di Kabupaten/ Kota sesuai dengan Surat Edaran Menteri Pendidikan Nasional Nomor 33/MPN/2007 yang ditujukan kepada, diantaranya para Bupati dan Wali Kota seluruh Indonesia. Di beberapa daerah diperoleh informasi bahwa bila surat keputusan disahkan oleh Bupati/Wali Kota, maka akan sangat dimungkinkan adanya kemudahan untuk memperoleh dana bagi kegiatan anggota TPK dari pemerintah daerah.

Menurut sebagian responden, Surat Keputusan Pengangkatan anggota TPK sering berubahubah. Perubahan tersebut diakibatkan oleh berbagai faktor, antara lain adanya perpindahan tugas beberapa anggota yang tidak memungkinkan lagi ikut terlibat dalam kegiatan TPK, sebagian ada yang memasuki masa pensiun dan pertimbangan lainnya guna lebih meningkatkan mutu/ kinerja anggota yang lebih baik. Dalam hal pendistribusian surat pengangkatan di beberapa daerah, terjadi kondisi dimana surat keputusan terlebih dahulu diterima oleh petugas pusat ketika sedang berada di daerah sampel dalam rangka pengumpulan data, sementara anggota TPK sejak awal hingga akhir kegiatan tidak menerimanya.
Sebagian responden dijanjikan akan menerima surat keputusan pengangkatan mereka sebagai anggota TPK Kabupaten/Kota, namun ketika petugas pusat yang sama datang kembali ke tempat yang sama pada tahun berikutnya, surat keputusan yang dijanjikan tidak terealisasi karena berbagai alasan.

\section{Struktur Kepengurusan}

Berdasarkan analisis data, struktur kepengurusan TPK Kabupaten/Kota pada umumnya relatif sama, terdiri dari; Pembina, Pengarah, Ketua, Sekretaris, Wakil Sekretaris, Bendahara dan anggota. Semua pengurus berasal dari Dinas Pendidikan, yang meliputi Kepala Dinas, Kepala Bidang, dan Pengawas. Sedangkan yang menjadi anggota adalah unsur Pengawas lainnya, Kepala Sekolah, dan guru dari Pendidikan anak usia dini (PAUD), SD, SMP, SMA, SMK, SLB. Jumlah pengurus dan anggota bervariasi dari satu daerah dengan daerah lainnya, antara limapuluh empat hingga sembilan puluh empat orang. Adanya pengurus dari Dinas pendidikan Kabupaten/Kota diharapkan akan memperkokoh kepengurusan TPK. Hal ini juga diharapkan adanya peningkatan perhatian yang lebih dari pemerintah daerah dan Dinas Pendidikan setempat terhadap keberadaan tim pengembang tersebut untuk memberdayakan anggotanya, mengingat pengalaman sebelumnya bahwa anggota TPK di provinsi kurang atau tidak dimanfaatkan secara maksimal.

\section{Dana}

Menurut sebagian responden, dana dari Dinas Pendidikan setempat belum ada dan di daerah lainnya dinyatakan sudah ada tetapi kurang memadai. Di daerah yang belum menyediakan dana, pihak Dinas Pendidikan ada yang menggunakan dana BOS yang tersedia untuk setiap sekolah. Ada Dinas Pendidikan yang berupaya bekerjasama dengan instansi non pemerintah guna mengatasi kekurangan dana yang diperlukan. Hubungannya dengan penggunaan dana BOS, para pengawas berkoordinasi dan bekerjasama dengan pihak sekolah yang ada di wilayah tugas mereka untuk menyelenggarakan kegiatan baik berupa sosialisasi maupun pendampingan untuk menyusun kurikulum sekolah. Tetapi pada pelaksanaannya, dana tersebut dirasa masih jauh 
dari cukup sehingga masih belum maksimal dalam memberdayakan anggota TPK. Di daerah sampel lain ada dana berasal dari provinsi secara khusus untuk untuk kegiatan serupa, namun juga masih jauh dari jumlah yang diharapkan apalagi mendapatkannya hanya satu kali saja mengingat pembagiannya bergantian dengan sekolah lain.

Ketidaktersediaan dana patut dipertanyakan karena payung hukumnya sudah jelas, ada Undang-Undang Dasar 45 yang telah diamandemen dengan penekanan kepada peningkatan anggaran pendidikan (Bab XIII Tentang Pendidikan dan Kebudayaan, Pasal 31 ayat 4 (WIKISOURCE). Aplikasi, Undang-Undang tersebut di dukung oleh Surat Edaran Menteri Pendidikan Nasional Nomor 33/MPN/2007, namun dapat disimpulkan kedua kebijakan belum terlaksana di lapangan dengan baik.

Di dalam surat keputusan pengangkatan anggota TPK di beberapa daerah sampel dinyatakan bahwa segala biaya yang dikeluarkan sebagai akibat ditetapkan keputusan ini dibebankan pada APBD Kabupaten. Tetapi pada kenyataannya ungkapan tersebut tidak serta merta merupakan jaminan yang dapat diharapkan dana tersedia dan mencukupi untuk kegiatan TPK. Kurangnya dana mengakibatkan kurang dioptimalkan anggota TPK diberdayakan yang berdampak pada berbagai hal, antara lain tidak terpenuhi harapan semua sekolah sudah menggunakan KTSP hingga batas akhir, tahun ajaran 2009/2010 (Permendiknas Nomor 24 Tahun 2006).

\section{Pemahaman Substansi}

Data menunjukkan sebagian kecil anggota TPK di beberapa daerah sampel belum memahami berbagai hal yang ada kaitannya dengan SI 2006 dan standar proses 2007, antara lain mengenai: KTSP, siapa yang menyusunnya, bagaimana sistematikanya dan siapa yang mengesahkannya, menjabarkannya hingga menjadi rencana pelaksanaan pembelajaran (RPP); penambahan waktu empat jam pembelajaran; pendekatan tematik di kelas rendah (kelas 1, 2, dan 3) di SD; program life skill atau keterampilan hidup; muatan lokal; batasan tugas terstruktur dan tidak terstruktur di SD, SMP dan SMA serta yang sederajat dan kesemuanya ini diuraikan di dalam SI 2006 dan standar proses 2007.
Sebagian responden masih belum memahami tentang siapa yang membuat KTSP, apa saja komponennya, cara membuatnya, sistematika penulisannya, dan yang mengesahkannya. Disamping itu ada responden yang belum memahami cara menjabarkan KTSP hingga menjadi RPP.

Sebenarnya yang membuat kurikulum satuan pendidikan adalah "sekolah dan komite sekolah, atau madrasah dan komite madrasah" (ayat 2, pasal 17, PP Nomor 19, Tahun 2005). Ungkapan tersebut dapat diartikan bahwa yang berhak atau terlibat dalam penyusunan kurikulum adalah guru dan kepala sekolah serta orang dari luar yang berfungsi sebagai anggota komite. Dalam hal komite sekolah, sebenarnya jangan hanya melihat dari sisi statusnya sebagai komite, tetapi harus dilihatnya dari sisi perhatian dan kompetensinya dalam bidang pendidikan. Dilibatkan dalam penyusunan kurikulum, namun kurang kompeten dalam melaksanakan tugasnya kemungkinan hal ini akan kurang bermanfaat. Ada warga di sekitar sekolah, statusnya bukan sebagai anggota komite, namun dipandang mampu membantu pengembangan sekolah, khususnya dalam bidang pengembangan kurikulum, dia lah yang sebaiknya dilibatkan. Khusus untuk pengembangan kurikulum sekolah kejuruan akan lebih baik bila melibatkan pihak Dunia usaha dan dunia industri (DUDI) agar lebih memahami hal-hal yang relevan yang perlu diketahui dan dicapai oleh peserta didik dari satuan tersebut. Sehingga ketika peserta didik lulus dari jenjang ini tidak ada discrepancy antara kemampuan lulusan dan kemampuan tuntutan dari dunia kerja tersebut. Karena itu keterlibatan pihak luar sangat ditekankan tentang hal ini. (Rachel Bolstad, 2004).

Pengembang KTSP secara fleksibel mengembangkan kurikulum sesuai dengan kebutuhan sekolah dan kesesuaian dengan lingkungannya. Tetapi "pengembangan.... memperhatikan panduan penyusunan kurikulum tingkat satuan pendidikan dasar dan menengah yang disusun Badan Standar Nasional Pendidikan" (Ayat 3, Pasal 1, Permendiknas Nomor 24, Tahun 2006). Tentunya komponen yang harus dicantumkan di dalam KTSP menjadi pertimbangan para penyusun itu sendiri. BSNP menyebutkan komponen besarannya terdiri dari " Tujuan pendidikan tingkat 
satuan pendidikan, struktur dan muatan kurikulum tingkat satuan pendidikan serta kalender pendidikan"(BSNP, 2006).

Berdasarkan hasil wawancara, perbedaan sistimatika penulisan terjadi karena nara sumber yang mendampingi/membantu mereka berbeda yang akhirnya hal ini membingungkan sebagian responden. Rendahnya kualitas serta kekurangan dalam hal komponen di dalam kurikulum mereka lebih disebabkan karena frekuensi kesempatan untuk berkomunikasi secara langsung dengan nara sumber belum maksimal. Begitu pula dengan adanya kurikulum hasil adopsi dari kurikulum sekolah lain. Di dalam panduan BSNP belum ditemukan frasa "komponen yang wajib dicantumkan di dalam kurikulum sekolah meliputi...." dan karena itu, kenyataan di lapangan menunjukkan adanya perbedaan penulisan KTSP. Sebagian responden menganggap perbedaan itu tidak merupakan masalah, namun sebagian lagi menganggap sebaliknya. Karena itu hampir di semua daerah sampel timbul pertanyaan tentang adanya perbedaan sistematika penulisannya.

Kurikulum yang telah selesai disusun kemudian ditetapkan oleh kepala satuan pendidikan dasar dan menengah setelah memperhatikan pertimbangan dari Komite Sekolah atau Komite Madrasah (Ayat 5, Pasal 1, Permendiknas Nomor 24, Tahun 2006). Panduan rinci tentang bagaimana menyusun KTSP, komponen apa yang tertuang di dalamnya serta menjabarkannya hingga menjadi RPP dapat dilihat di dalam Panduan BSNP Tentang Panduan Penyusunan Kurikulum Tingkat Satuan Pendidikan Jenjang Pendidikan Dasar dan Menengah, Tahun 2006. Sebagian responden mengalami kesulitan dalam mengembangkan KTSP di sekolah pedalaman yang jumlah gurunya masih relatif kurang.

Permasalahan ini sebenarnya dapat dijadikan bahan instrospeksi bagi para penentu kebijakan di daerah tersebut. Kenapa hal ini terjadi sementara penggunaan KTSP telah diberlakukan selama 3 tahun dan batas akhir dimulai penggunaannya pada tahun ajaran 2009/2010 (Permendiknas Nomor 24 Tahun 2006). Alasan kurangnya dana sebenarnya bukan satu-satunya yang menciptakan tidak terlaksananya KTSP di sekolah pedalaman, namun juga disebabkan kurang maksimalnya fungsi dan tugas para pengawas setempat untuk menjangkau daerah tersebut. Tugas mereka antara lain mengunjungi, memberi pelayanan dan pengetahuan kepada bawahannya, yaitu kepala sekolah dan guru di wilayah binaannya secara merata. Dengan memberi pelayanan secara rutin, tentunya sekolah di pedalaman juga berhak memperoleh bantuan dari pengawas secara rutin pula, termasuk berbagai informasi baru yang berkaitan dengan tugas mereka.

Disadari atau tidak biasanya dalam inovasi pendidikan apapun biasanya yang ditatar terlebih dahulu adalah bukan pengawas, melainkan guru. Karena itu sering terjadi di berbagai daerah bahwa pengetahuan guru dalam hal memperoleh informasi baru lebih awal dari pada pengawasnya. Karena itu pengawas sering merasa kurang yakin akan kemampuannya dalam menyampaikan materi terkini yang sebenarnya harus disampaikan kepada guru. Sebagai konsekuensinya biasanya pengawas mengkritisi tentang administrasi saja yang sifatnya statis.

Sebagian responden mengakui bahwa di daerah mereka masih ada sekolah yang mengadopsi KTSP dan ada yang sudah mengadaptasi. Kondisi tersebut tidak menyalahi aturan karena "Satuan pendidikan dasar dan menengah dapat mengadopsi atau mengadaptasi model kurikulum tingkat satuan pendidikan dasar dan menengah yang disusun oleh BSNP" (Permendiknas Nomor 24 Tahun 2006). Mengenai adanya kurikulum hasil adopsi dari sekolah lain, hal ini juga perlu dibenahi dengan aturan yang tegas sampai kapan batasan suatu sekolah diperbolehkan mengadopsi kurikulum sekolah lain. Bila suatu sekolah dibiarkan mengadopsi tanpa batas waktu, kapan warga sekolah menjadi kreatif dan berkembang dalam meningkatkan mutu peserta didik mereka.

Sebagian responden masih mengalami kesulitan untuk mengkaitkan antara analisis konteks dengan KTSP dan bentuk analisis serta cara menuangkannya ke dalam KTSP. Analisis konteks telah dibahas di dalam Panduan penyusun KTSP tahun 2006, artinya telah ada gagasan tentang hal ini sejak ada gagasan pengembangan kurikulum sekolah. Tetapi substansinya, perlu diakui, adanya belakangan sehingga sosialisasinya ke daerah/sekolah baru dimulai tahun 2009. Idealnya ketika akan 
menyusun KTSP, pihak sekolah telah diberi pemahaman tentang analisis konteks, apa itu analisis konteks, bagaimana melaksanakannya, dan apa hasil dari analisis tersebut, dan apa pengaruhnya terhadap penyusunan KTSP. Karena keberadaan substansi tentang analisis konteks belakangan, maka timbul pertanyaan seperti di atas. Karena itu pada waktu yang akan datang materi analisis konteks tetap disosialisasikan kepada instansi terkait, kepala sekolah dan guru secara komprehensif dan berkesinambungan agar mereka lebih memahaminya secara baik sehingga kurikulum mereka benar-benar akan sesuai dengan kondisi peserta didik serta lingkungan mereka karena penyusunannya berdasarkan kebutuhan dan kondisi lingkungan mereka yang ada.

Data menunjukkan pada umumnya responden telah menerima contoh silabus dan RPP dari BSNP, namun sebagian belum memahami apakah mereka diperbolehkan mengurangi atau menambah SK dan KD yang ada di dalam contoh tersebut. Sebagian dari mereka juga belum memahami tentang silabus dan RPP untuk semua mata pelajaran harus dicantumkan di dalam KTSP. Sebenarnya yang namanya contoh, sifatnya masih fleksibel yaitu boleh dimodifikasi dalam arti dikurangi atau ditambah. Tetapi khusus jumlah SK dan KD seperti yang ada di contoh sebaiknya jangan dikurangi karena itu sudah dikatakan minimal. Disamping itu, bila sebagian dari yang ada dan minimal ini dibuang, kemudian yang dibuang pada kenyataannya dijadikan rujukan oleh penyusun soal ujian nasional, maka peserta didik dari sekolah yang gurunya membuang SK dan KD tentunya akan mengalami kesulitan dalam menjawab soal.

Sebagian responden belum memahami mengenai perlu tidaknya penggabungan silabus dan RPP dengan dokumen KTSP. Sebenarnya itu masalah teknis, dapat ditafsirkan harus masuk, dapat juga tidak. Yang penting adalah adanya benang merah yang jelas antara SI, silabus, RPP dan kegiatan pembelajaran yang melibatkan peserta didik aktif dalam belajara serta penilaian untuk masing-masing mata pelajaran. Pada awal pengembangan KTSP, silabus dan RPP merupakan lampiran dari KTSP. Tetapi ketika Pusat Kurikulum berdiskusi dengan para guru, mereka mengusul- kan kepada Pusat Kurikulum untuk mengubah istilah "lampiran" menjadi "Buku II" dengan alasan istilah lampiran dapat dimaknai sebagai pelengkap yang kurang bermakna. Sedangkan fungsi silabus dan RPP sangat jelas bagi guru sebagai pedoman utama dalam melaksanakan tugas mereka sehari-hari, itulah argumen mereka yang pada akhirnya sekarang istilah Buku II dikenal di mana-mana.

Sebagian responden masih belum mengetahui cara mengatasi apabila ada mata pelajaran yang kurang alokasi waktunya. Sebenarnya hal tersebut dapat didiskusikan dengan kepala sekolah dan guru lain. Apalagi dengan kebijakan yang berlaku dimana ada waktu tambahan empat jam pelajaran yang secara fleksibel dapat digunakan untuk mata pelajaran apa saja yang dianggap perlu ditambah jamnya. Di beberapa sekolah ada kebijakan empat jam tambahan dialokasikan masing-masing satu jam untuk setiap mata pelajaran yang di UN kan, misalnya Bahasa Inggris, Bahasa Indonesia, Matematika dan IPA. Contohnya, jam pelajaran Bahasa Inggris di SMP secara resmi tertuang empat jam, namun karena ada kebijakan sekolah untuk menambah satu jam lagi, maka pada pelaksanaannya menjadi lima jam. Kebijakan sekolah dalam memanfaatkan jam tambahan ini pada kenyataannya berbeda-beda, dan bahkan ada sekolah yang belum memanfaatkannya karena belum memahami penggunaan ke empat jam tambahan tersebut.

Mengenai adanya pendekatan tematik di kelas 1 sampai $3 \mathrm{SD}$, sebagian responden belum memahami manfaat dari pendekatan tersebut, cara penyusunan silabus dan RPP nya serta pengaplikasiannya di dalam kelas. Sebagian responden belum memahami bagaimana pembagian jam untuk kelas rendah dengan pendekatan itu. Berdasarkan SI, pendekatan pembelajaran yang digunakan di kelas 1 sampai dengan kelas 3 SD adalah pendekatan tematik, sedangkan sebelumnya "pendekatan mata pelajaran" (Lampiran SI 2006: Struktur Program, Bab II Kerangka Dasar dan Struktur Kurikulum). Pendekatan ini lebih cenderung seperti pendekatan yang digunakan di Taman Kanak-Kanak dimana materi pembelajaran dari berbagai mata pelajaran diikat oleh suatu tema dengan maksud akan mempermudah peserta didik memahami materi yang mereka 
terima tanpa harus dipikirkan dari mata pelajaran apa. Materi yang diikat tentunya yang relevan dengan tema yang digunakan sehingga peserta didik merasakan kenyamanan dalam menerima materi dimaksud.

Menurut sebagian para ahli, ada perbedaan jumlah peserta didik di kelas rendah yang dropout dan mengulang antara yang belajar melalui pendekatan tematik dan pendekatan mata pelajaran. "Mereka yang belajarnya melalui pendekatan tematik, tingkat persentase "dropout" dan mengulang kelas lebih sedikit dibanding mereka yang mengikuti pembelajaran melalui pendekatan mata pelajaran" (Puskur 2007a). Karena pendekatan tematik ini merupakan hal baru di SD kelas rendah, realita di lapangan menunjukkan bahwa hampir semua responden dari kelas rendah tersebut mangalami kesulitan dalam memahami dan melaksanakan pembelajarannya, termasuk perencanaannya. Faktor lain yang menyebabkan responden mengalami kesulitan adalah, menurut sebagian responden, karena pihak Dinas Pendidikan kurang proaktif menyelenggarakan seminar atau workshop khusus bagi guru yang mengajar di kelas rendah. Sementara pemahaman tertang hal tersebut sangat diperlukan oleh responden untuk melaksanakan tugas mereka di kelas dan tugas mereka sebagai tim pengembang kurikulum untuk mensosialisasikannya kepada guru lain di wilayah mereka masing-masing.

Sebagian responden belum memahami tentang life skill dalam KTSP serta cara menerapkannya, dan bahkan ada diantara responden yang belum mengetahui makna dari kata "Life skill" dalam kurikulum sekolah. Sebenarnya istilah "life skill" yang digunakan di dalam KTSP memiliki makna "kecakapan hidup". Cakap dapat diartikan terampil, terampil dalam berbagai aspek kehidupan yang di dalam Model Integrasi Pendidikan Kecakapan Hidup, Pusat Kurikulum Tahun 2007 dinyatakan ada lima jenis, yaitu: "1) kecakapan mengenal diri, 2) kecakapan berpikir, 3) kecakapan sosial, 4) kecakapan akademik, dan 5) kecakapan kejuruan. Jadi terampil dalam hidup atau kehidupan seseorang perlu guna menghadapi berbagai kondisi dan situasi sehingga seseorang dapat hidup secara mandiri". Pendidikan Kecakapan Hidup diajarkan di sekolah terpadu dengan semua mata pelajaran, jadi bukan mata pelajaran sendiri. Karenanya di dalam struktur program untuk KTSP tidak tercantum mata pelajaran kecakapan hidup sehingga tidak berdampak adanya penambahan jam pelajaran.

Sebagian responden belum memahami tentang: status muatan lokal, perlu tidaknya muatan lokal di tingkat SMA dan sederajat, penyusunan SK dan KD nya, pelaksanaannya dan pencantuman nilainya. Muatan Lokal (Mulok) merupakan "payung" dari satu atau beberapa mata pelajaran yang diajarkan di sekolah sebagai hasil dari pengembangan kurikulum di daerah. Mata pelajaran yang ada di dalam lingkup Mulok statusnya bukan wajib dilihat dari sisi kebijakan pemerintah. Artinya sekolah dibebaskan untuk memilih mata pelajaran yang diharapkan sesuai dengan kebutuhan daerah dan materinya tidak tercakup di mata pelajaran yang diwajibkan. "Substansi mata pelajaran muatan lokal ditentukan oleh satuan pendidikan di sesuaikan dengan karakteristik daerah masing-masing" (Puskur, 2007).

Keberadaan Mulok di satuan pendidikan jenjang pendidikan dasar dan menengah menjadi penting agar ada kegiatan penggalian potensi daerah yang akan menyeimbangan antara "kepentingan nasional dan kepentingan daerah harus saling mengisi dan memberdayakan sejalan dengan motto Bhineka Tunggal Ika dalam rangka Negara Kasatuan Republik Indonesia" (BSNP 2006).

Pemerintah tidak menyediakan SK dan KD Mulok untuk satuan pendidikan jenjang pendidikan dasar dan menengah, tetapi daerah yang berwenang menyusunnya karena dianggap lebih mengetahui potensi daerah serta kemampuan peserta didik mereka. Cara menyusunnya, lihat secara cermat SK yang dijabarkan menjadi KD untuk mata pelajaran lain, lingkup pembahasan antara SK dan KD dilihat dari jumlah dan kerinciannya di mata pelajaran lain bila tidak ada nara sumber yang dapat diajak bekerjasama untuk berdiskusi. Pelaksanaan mulok mulai sejak SD kelas satu hingga SMA kelas dua belas.

Walaupun muatan lokal ditentukan oleh satuan pendidikan, pada kenyataannya sebagian pemerintahan daerah (Provinsi dan Kabupaten/ 
Kota) juga mewajibkan sekolah melaksanakan mata pelajaran Mulok sehingga di suatu sekolah ada dua mata pelajaran Mulok, dari sekolah dan pemerintah daerah, namun kondisi ini tidak terjadi di semua daerah sampel. Bila ada dua mata pelajaran muatan lokal dalam satu tahun di suatu sekolah, pelaksanaannya dapat diatur satu semester satu mata pelajaran mulok sehingga kedua mulok dapat diajarkan dalam satu tahun. Pencantuman nilainya, bila tidak ada ruang di dalam ijazah dari pusat, pihak sekolah dapat merancang sendiri di lembaran terpisah.

Sebagian responden belum memahami tentang perbedaan "tugas mandiri terstruktur" dan "tugas mandiri tidak terstruktur" dalam kegiatan pembelajaran. Informasi pengertian tentang kedua hal tersebut tertuang di dalam SI, tepatnya pada Bab III tentang Beban Belajar (Lampiran SI 2006, tentang Struktur Program). Ditegaskan bahwa tugas mandiri terstruktur adalah "kegiatan pembelajaran yang berupa pendalaman materi pembelajaran oleh peserta didik yang dirancang oleh pendidik untuk mencapai standar kompetensi. Waktu penyelesaian penugasan terstruktur ditentukan oleh pendidik. Sedangkan tugas mandiri tidak terstruktur adalah kegiatan pembelajaran yang berupa pendalaman materi pembelajaran oleh peserta didik yang dirancang oleh pendidik untuk mencapai standar kompetensi dan waktu penyelesaiannya diatur sendiri oleh peserta didik". Yang penting dalam hal memberi tugas mandiri terstruktur dan tidak tersetruktur harus diperhatikan dengan perbandingan jumlah waktu tatap muka untuk setiap mata pelajaran. Para ahli tentunya telah mempertimbangkan dilihat dari berbagai hal tentang perbandingan waktu ini. Karena itu bagi peserta didik SD dan sederajat maksimum $40 \%$ dari jumlah waktu kegiatan tatap muka dari mata pelajaran yang bersangkutan. Bagi peserta didik di tingkat SMP dan sederajat maksimum $50 \%$ dari jumlah waktu kegiatan tatap muka dari mata pelajaran yang bersangkutan. Sedangkan bagi peserta didik SMA dan sederajat maksimum $60 \%$ dari jumlah waktu kegiatan tatap muka dari mata pelajaran yang bersangkutan.

\section{Pemberdayaan anggota TPK}

Menurut sebagian responden yang juga sebagai anggota TPK tersebut di semua daerah sampel bahwa mereka belum dan kurang diberdayakan secara maksimal untuk mensosialisasikan kebijakan pemerintah yang berkaitan dengan kurikulum satuan pendidikan jenjang pendidikan dasar dan menengah serta mendampingi sekolah menyusun kurikulum. Tidak dan kurang diberdayakan, menurut versi Dinas Pendidikan di beberapa daerah, karena berbagai hal termasuk kurangnya dana, alih tugas, tingkat pemahaman/kompetensi mereka. Mereka ada yang mengajar di PAUD, SD, SMP, SMA, SMK, dan SLB. Akibat dari kurang proaktif Dinas Pendidikan dalam melibatkan semua yang telah diangkat menjadi anggota TPK Kabupaten/ Kota dimungkinkan kurang cepat mengebar pelaksanaan KTSP di sekolah secara cepat dan merata.

\section{Pelaksanaan KTSP}

Sejak diberlakukan SI tahun 2006 pemberlakuan KTSP sudah tiga tahun berlangsung, namun pada tingkat pelaksanaannya di sekolah masih bervariasi. Sebagian sekolah ada yang baru mengadopsi kurikulum sekolah lain, sebagian ada yang telah mengadaptasi disesuaikan dengan lingkungan, kebutuhan daerah dimana sekolah berada dan kemampuan peserta didik dan sebagian lagi belum melaksanakan KTSP. Bahkan ada responden ketika di Dinas Provinsi mengatakan bahwa semua sekolah di wilayahnya telah melaksanakan KTSP, sedangkan ketika ke petugas Pusat Kurikulum nyampaikan informasi yang bertolak belakang. Tetapi penulis percaya bahwa belum semua sekolah di daerah itu melaksanakan KTSP apalagi setelah memperoleh informasi dari beberapa responden tentang tidak adanya dana dan nara sumber yang didatangkan ke daerah itu. Ditelusuri tentang kenapa responden tersebut mengungkapkan yang berbeda di provinsi, alasannya dikatakan karena merasa malu oleh peserta lain yang datang dari Kabupaten lain. Kondisi ini menunjukkan bahwa Peraturan Menteri Pendidikan Nasional Nomor 24 Tahun 2006 Tentang Pelaksanaan Permendiknas Nomor 22 dan 23 Tahun 2006 dimana diharapkan semua sekolah telah melaksanakan KTSP paling lambat tahun ajaran 2009/2010 pada kenyataannya belum dilaksanakan secara penuh. Inilah fenomena pelaksanaan KTSP di daerah sampel yang masih jauh dari harapan walaupun instansi pusat 
seperti Pusat Kurikulum selama ini telah beberapa tahun membina anggota TPK Kabupaten/Kota.

\section{Simpulan dan Saran}

Simpulan

Ada beberapa kesimpulan dari hasil penelitian yang diselenggarakan di dua belas Kabupaten/ Kota yang menjadi daerah sampel sebagai berikut: 1) Pihak Dinas Pendidikan Kabupaten/ Kota telah membentuk TPK dengan surat mengangkatan yang disahkan oleh Kepala Dinas Pendidikan atau oleh Bupati. 2) Di semua daerah sampel ada struktur kepengurusan TPK yang pada umumnya relatif sama, terdiri dari: Pembina, Pengarah, Ketua, Sekretaris, Wakil Sekretaris, Bendahara dan anggota. Semua pengurus berasal dari Dinas Pendidikan, yang meliputi Kepala Dinas, Kepala Bidang, dan Pengawas. Sedangkan yang menjadi anggota TPK adalah unsur Pengawas, Kepala Sekolah dan guru dari Pendidikan anak usia dini (PAUD), SD, SMP, SMA, SMK, SLB. Jumlah pengurus dan anggota bervariasi dari satu daerah dengan daerah lainnya, antara lima puluh empat hingga sembilan puluh empat orang. 3) Di sebagian besar daerah sampel, Pihak Dinas Pendidikan tidak memiliki dana yang dianggap cukup bagi kegiatan anggota TPK. Namun di sebagian daerah pihak Dinas berupaya mengatasi kekurangan dana tersebut melalui bekerjasama dengan instansi yang relevan. Di beberapa daerah lainnya, Dinas Pendidikan menggunakan dana BOS yang ada di sekolah. 4) Sebagian kecil anggota TPK di semua daerah belum memahami informasi yang berkaitan dengan kurikulum secara baik; 5) Anggota TPK Kabupaten/Kota tidak diberi kesempatan yang relatif sama untuk melaksanakan tugas pokoknya mensosialisasikan kebijakan pemerintah termasuk panduan dan petunjuk teknis yang berkaitan dengan kurikulum; 6) Di sebagian daerah masih ada sekolah yang belum memiliki dan melaksanakan kurikulum mereka masing-masing walaupun pemerintah telah menganjurkannya tiga tahun sebelumnya.

\section{Saran}

Beberapa saran yang ada kaitannya dengan kesimpulan di atas sebagai berikut: Sebaiknya dana jangan selalu dijadikan alasan utama tidak mengoptimalisasikan anggota TPK Kabupaten/ kota untuk mensosialisasikan informasi tentang kebijakan pemerintah yang berkaitan dengan kurikulum jenjang pendidikan dasar dan menengah dan mendampingi sekolah mengembangkan kurikulum mereka. Bila selalu dikaitkan dengan dana, sangat mungkin anggota TPK tidak akan maksimal melaksanakan tugas pokok mereka. Karena itu pihak Dinas Kabupaten/Kota, sebagai penentu kebijakan pendidikan di daerah, sebaiknya mengambil langkah tegas dalam meningkatkan mutu pendidikan di wilayahnya yaitu mewajibkan anggota TPK menghadiri kegiatan rutinnya baik dalam bentuk paparan maupun workshop yang berkaitan dalam pengembangan kurikulum. Mengenai adanya sebagian anggota TPK yang belum memahami secara baik mengenai kebijakan, panduan dan atau petunjuk teknis yang berkaitan dengan kurikulum sekolah, ini kemungkinan karena kurangnya upaya Dinas setempat memberdayakan mereka secara maksimal. Karena itu, kedepan semua anggota sebaiknya diberdayakan secara merata baik dalam hal peningkatan pengetahuan/wawasan dan keterlibatan mereka dalam mensosialisasikan berbagai informasi yang berkaitan dengan KTSP dan mendampingi sekolah menyusun kurikulum. Bila hal ini dilaksanakan, optimis sekali tidak ada sekolah yang belum melaksanakan KTSP pada tahun ketiga pemberlakuan kebijakan sekolah memiliki dan melaksanakan kurikulum kurikulum sendiri.

\section{Pustaka Acuan}

Badan Standar Nasional Pendidikan. 2006. Komponen Kurikulum, Panduan Penyusunan Kurikulum Tingkat Satuan Pendidikan Jenjang Pendidikan Dasar dan Menengah, Jakarta.

Cameron, L. 2001. Teaching Languages to Young Learners. Cambridge Language Teaching Library. Cambridge, Cambridge University Press.

Departemen Pendidikan Nasional. 2003. Nomor 20 tentang Undang-Undang Sistem Pendidikan Nasional, Jakarta.

Peraturan Pemerintah Nomor 19, 2005. tentang Standar Nasional Pendidikan, Jakarta. 
- Nomor 38, 2007. tentang Pembagian Urusan Pemerintahan AntaraPemerintah, Pemerintahan Daerah Provinsi, dan Pemerintahan Daerah Kabupaten/Kota, Jakarta.

Peraturan Menteri Pendidikan Nasional. Lampiran Nomor 22, 2006. tentang Kerangka Dasar dan Struktur Kurikulum, Departemen Pendidikan Nasional, Jakarta.

. Nomor 23, 2006. tentang Standar Kompetensi Lulusan untuk Satuan Pendidikan Dasar dan Menengah. Departemen Pendidikan Nasional. Jakarta.

. Nomor 24, 2006. tentang Pelaksanaan Peraturan Menteri Pendidikan Nasional Nomor 22, tahun 2006 tentang Standar Isi untuk Satuan Pendidikan Dasar dan Menengah.

Pusat Kurikulum. 2006. Panduan Pengembangan Jaringan Kurikulum Tingkat Kabupaten/Kota, Badan Penelitian dan Pengembangan, Departemen Pendidikan Nasional, Jakarta. . 2007. Model Pengembangan Mata Pelajaran Muatan Lokal, Badan Penelitian dan Pengembangan, Departemen Pendidikan Nasional, Jakarta.

Rachel Bolstad, 2004. School-Based Curriculum Development: Principles, Processes, and Practices. http://www.nzcer.org.nz/default.php?products id=829, November 2004 (27 Desember 2009)

Surat Edaran Menteri Pendidikan Nasional Nomor 33/MPN/SE/2007 tentang Sosialisasi Kurikulum Tingkat Satuan Pendidikan, Departemen Pendidikan Nasional, Jakarta

WIKIPEDIA, 2009. The Free Encyclopedia. Competence (human resources). W http:/en.wikipedia.org/ wiki/Competence_(human_resources). This was last modified on 27 November 2009. (28 Desember 2009)

WIKISOURCE. Undang-Undang Dasar Republik Indonesia 1945 (Perubahan I s.d IV). http:/id. wikisource.org/wiki/Undang-Undang_Dasar_Republik_Indonesia_1945_(Perubahan_I_s.d._IV) (2 Februari 2010). 